\title{
Effect of Cooking on Cholesterol and Proximate Composition on Breast and Thigh Muscles of Chicken and Quail Meat
}

\author{
T. Nandini Devi*, R. Ramani, R. Narendra Babu, V. Appa Rao, \\ J. Ramesh and Robinson J.J. Abraham
}
Department of Livestock Products Technology (Meat Science), Madras Veterinary College, Tamil Nadu Veterinary and Animal Sciences University, Chennai-7, Tamil Nadu, India *Corresponding author

\author{
A B S T R A C T
}

\begin{tabular}{|c|}
\hline Keywords \\
\hline $\begin{array}{l}\text { Proximate, } \\
\text { Cholesterol, Fresh, } \\
\text { Cooked, Breast, } \\
\text { Thigh and Chicken. }\end{array}$ \\
\hline Article Info \\
\hline $\begin{array}{l}\text { Accepted: } \\
\text { 29 September } 2017 \\
\text { Available Online: } \\
10 \text { October } 2017\end{array}$ \\
\hline
\end{tabular}

A study to evaluate the effect of cooking on cholesterol and proximate composition of breast and thigh muscles of chicken meat and quail meat was carried out. Eight broilers were purchased from retail outlets in and around Chennai and were brought and slaughtered at Department of Livestock Products Technology (Meat Science), Madras Veterinary College, Chennai. Fresh and cooked meat samples from both breast and thigh region of chicken and quial were evaluated for the proximate composition and cholesterol content. Results of the study revealed that there was a highly significant difference $(\mathrm{P}<0.01)$ in moisture, protein, fat and no significant difference $(\mathrm{P}>0.05)$ in total ash content of breast meat of fresh and cooked meat in both the species. The study revealed highly significant difference $(\mathrm{P}<0.01)$ in protein, fat and a significant difference $(\mathrm{P}<0.05)$ in thigh meat and there was no significant difference $(P>0.05)$ in moisture, total ash content of breast and thigh region of fresh chicken meat. Also a highly significant difference $(\mathrm{P}<0.01)$ in protein, fat and a significant difference $(\mathrm{P}<0.05)$ in total ash content and no significant difference $(\mathrm{P}>0.05)$ in moisture and energy value of breast and thigh region of cooked chicken meat was reported in this study. Highly significant difference was observed in cholesterol content of fresh and cooked meat of both chicken and quail meat.

\section{Introduction}

Meat has exerted a crucial role in human evolution and is an important component of healthy and well balanced diet due to its nutritional richness. It is essential to know about the role of meat and its importance in human nutrition. The nutritive value of meat is attributed to its high quality protein, essential fatty acids, important minerals and B complex group of vitamins. Meat protein is superior to plant protein because of its high biological value.
Food of animal origin, particularly meat, suffers from a bad image in terms of dietetic value. It is often not recognized that meat substantially contributes to the supply with valuable or even essential nutrients.

Meat being incredibly nutritious and versatile has now been demonized as causing several health problems like coronary heart disease, colon cancer, obesity and type II diabetes, etc., and these problems are correlated with 
high saturated fat and cholesterol content in meat. Today's busy lifestyle gives rise to more erratic dietary practices leading to nutrient deficiency diseases. Owing to the increased consciousness on health, the present day consumers are more focused on quality and nutritional characteristics of meat.

Keeping in view the importance of eating lean meat with more protein and less cholesterol the study was aimed to determine the cholesterol and proximate status of breast and thigh of chicken meat when compared with quail meat.

\section{Materials and Methods}

The proximate composition such as moisture, protein, fat, ash and energy were analysed by following the standard procedure of AOAC (1995). Fat estimation was done in SOCS plus (Model SCS 4, Pelican Equipment Pvt. Ltd., Chennai) and protein estimation in KEL plus (Model Classic DX, Pelican Equipment Pvt. Ltd., Chennai) equipment available in the Department of Livestock Products Technology (Meat Science), Madras Veterinary College, Chennai-7.

Cholesterol content of fresh and cooked meat samples of chicken and quail meat were determined using cholesterol test kit (ROBONIK INDIA Pvt Ltd., India). Lipid extract was used instead of 7blood serum, as per the method described by Wybenga et al., (1970). Lipid extract was prepared by taking one gram of meat sample and adding ten $\mathrm{ml}$ of freshly prepared 2:1 chloroform: methanol solution and homogenizing in a laboratory blender.

The homogenate was then filtered using Whatman No. 42 filter paper and to the $5 \mathrm{ml}$ of filtrate equal quantity of distilled water was added, mixed and centrifuged at $3000 \mathrm{rpm}$ for $7 \mathrm{~min}$. After centrifugation the top layer (Methanol) was removed by suction and the volume of the bottom (Chloroform) layer having cholesterol was collected. From this, $25 \mu \mathrm{l}$ of the sample was pipetted in a test tube and kept in hot water bath at $100^{\circ} \mathrm{C}$ for $2-3$ minutes till it got dried. To this $5 \mathrm{ml}$ of cholesterol reagent was added, mixed and kept in boiling water bath for 90 seconds for colour development. The Absorbance (Abs) of standard and test against blank was taken at a wavelength of $510 \mathrm{~nm}$. The total cholesterol $(\mathrm{mg} / \mathrm{dl})$ of functional chicken nuggets was calculated as follows:

Conc. of unknown sample $=$

Conc. of standardx (Abs of unknown sampleAbs of blank)

(Abs of standard - Abs of blank)

\section{Results and Discussion}

The mean \pm S.E proximate composition (moisture, protein, fat, total ash content and energy value) of fresh and cooked meat were presented in Tables 1 and 2 along with test of significance.

There was a highly significant difference $(\mathrm{P}<0.01)$ in moisture, protein, fat and no significant difference $(\mathrm{P}>0.05)$ total ash content and there was a significant difference $(\mathrm{P}<0.05)$ in energy value of fresh and cooked chicken. The test of significance revealed highly significant difference $(\mathrm{P}<0.01)$ in moisture, protein, fat, energy value and there was no significant difference $(\mathrm{P}>0.05)$ in total ash content of thigh meat of fresh and cooked chicken. The test of significance revealed highly significant difference $(\mathrm{P}<0.01)$ in protein, fat (fresh) and a significant difference $(\mathrm{P}<0.05)$ in energy value (fresh) and cooked meat of total ash content and there was no significant difference $(\mathrm{P}>0.05)$ in moisture, fat (cooked), total ash content(fresh) and energy value (cooked) of breast and thigh region of fresh chicken meat. 
Table.1 Proximate composition of breast and thigh of fresh and cooked chicken

\begin{tabular}{|c|c|c|c|c|c|c|}
\hline \multirow{2}{*}{ Parameter } & \multicolumn{3}{|c|}{ Fresh } & \multicolumn{3}{|c|}{ Cooked } \\
\hline & Breast & Thigh & t- value & Breast & Thigh & t- value \\
\hline Moisture & $\begin{array}{c}70.86 \pm \\
0.50\end{array}$ & $\begin{array}{c}74.81 \pm \\
0.26\end{array}$ & $1.65^{\mathrm{NS}}$ & $\begin{array}{c}65.48 \pm \\
0.34\end{array}$ & $\begin{array}{c}68.16 \pm \\
0.26\end{array}$ & $0.73^{\mathrm{NS}}$ \\
\hline $\begin{array}{l}\text { Crude } \\
\text { Protein }\end{array}$ & $\begin{array}{c}23.71 \pm \\
0.48\end{array}$ & $\begin{array}{c}19.57 \pm \\
0.43\end{array}$ & $6.31 * *$ & $\begin{array}{c}27.87 \pm \\
0.47\end{array}$ & $\begin{array}{c}25.19 \pm \\
0.57\end{array}$ & $3.59 * *$ \\
\hline Crude Fat & $2.15 \pm 0.24$ & $2.63 \pm 0.20$ & $3.72 * *$ & $3.32 \pm 0.39$ & $3.59 \pm 0.15$ & $0.26 * *$ \\
\hline Total Ash & $1.24 \pm 0.33$ & $0.93 \pm 0.01$ & $2.29 * *$ & $1.76 \pm 0.06$ & $1.61 \pm 0.02$ & $2.29 * *$ \\
\hline Cholesterol & $\begin{array}{c}42.23 \pm \\
0.43\end{array}$ & $\begin{array}{c}49.71 \pm \\
0.44\end{array}$ & $15.38 * *$ & $\begin{array}{c}82.47 \pm \\
0.52\end{array}$ & $\begin{array}{c}74.48 \pm \\
0.58\end{array}$ & $13.58 * *$ \\
\hline
\end{tabular}

Table.2 Proximate composition of breast and thigh of fresh and cooked Quail

\begin{tabular}{|c|c|c|c|c|c|c|}
\hline \multirow{2}{*}{ Parameter } & \multicolumn{3}{|c|}{ Fresh } & \multicolumn{3}{|c|}{ Cooked } \\
\hline & Breast & \begin{tabular}{|l|} 
Thigh \\
\end{tabular} & t- value & \begin{tabular}{|l|} 
Breast \\
\end{tabular} & $\begin{array}{l}\text { Thigh } \\
\end{array}$ & t- value \\
\hline Moisture & $73.49 \pm 0.39$ & $73.81 \pm 0.29$ & $3.66 *$ & $65.54 \pm 0.55$ & $67.76 \pm 0.59$ & $2.75 *$ \\
\hline $\begin{array}{c}\text { Crude } \\
\text { Protein }\end{array}$ & $24.14 \pm 0.65$ & $21.18 \pm 0.51$ & $3.55 * *$ & $27.67 \pm 0.50$ & $24.55 \pm 0.47$ & $4.48 * *$ \\
\hline Crude Fat & $2.49 \pm 0.08$ & $2.81 \pm 0.26$ & $5.31 * *$ & $3.27 \pm 0.14$ & $4.35 \pm 0.20$ & $7.09 * *$ \\
\hline Total Ash & $1.29 \pm 0.06$ & $1.17 \pm 0.03$ & $15.42 * *$ & $2.49 \pm 0.05$ & $2.44 \pm 0.02$ & 12.16** \\
\hline Cholesterol & $62.15 \pm 0.37$ & $68.33 \pm 0.67$ & $0.47^{\mathrm{NS}}$ & $84.04 \pm 2.04$ & $90.27 \pm 3.67$ & $1.86^{\mathrm{NS}}$ \\
\hline
\end{tabular}

The test of significance revealed highly significant difference $(\mathrm{P}<0.01)$ in moisture, protein, fat and total ash content and there was no significant difference $(\mathrm{P}>0.05)$ in energy value of breast meat of fresh and cooked Japanese quail. The test of significance revealed highly significant difference $(\mathrm{P}<0.01)$ in moisture, protein, fat, total ash content and there was no significant difference $(\mathrm{P}>0.05)$ in the energy value of thigh meat of fresh and cooked Japanese quail.

A decrease in moisture content with a concomitant increase in the other constituents of cooked meat samples of both species was noticed in this study which was in congruence with the note made by Sales (1997) in ostrich meat. The mean fat percentage in the fresh and cooked meat sample of breast muscle of both species were lower than the mean fat percentage in thigh muscle. This finding was in contrast with the result obtained by Mazanowski and Ksiazkiewicz (2004) in Pekin ducks and Isguzar et al., (2002) in local ducks and Turkish Pekins. The protein content of both fresh and cooked breast meat samples of both species were significantly higher when compared to that of the values of fresh and cooked thigh meat samples of both. Similar results were obtained by Tejerina et al., (2009). Highly significant difference was observed in cholesterol content of fresh and cooked meat of both chicken and quail meat. The breast meat of chicken was found to have more cholesterol compared to thigh meat. But there is no significant difference was observed in quail meat. Cooked meat of chicken is having more protein content compared to quail meat which can be considered as important criterion in formulating dietary schedule for daily protein requirement for both paediatric and geriatric groups. 


\section{Acknowledgement}

This manuscript forms the part of the thesis submitted by first author to Tamil Nadu Veterinary and Animal Sciences University.

\section{References}

AOAC (Association of Official Analytical Chemist), 1995. Official methods of Analysis, $16^{\text {th }}$ Ed., Virginia, U.S.A.

Işguzar, E.R, C.E. Kocak, and H. Pingel, 2002. Growth, carcass traits and meat quality of different local ducks and Turkish Pekins. Arch. Tierz., Dummerstorf, 45, 413-418.

Mazanowski, A., and Ksiazkiewicz, J., 2004. Comprehensive evaluation of meat traits of ducks from two sire strains. Journal of Animal and Feed Sciences, 13(1):
173-182.

Sales, J., 1997. Effect of cooking on the quality of ostrich muscles. Journal of Food Science and Technology, Pp 520521.

Tejerina, D., M. M. Lopez-Parra and S. Garcia-Torres, 2009. Potential used of near infrared reflectance spectroscopy to predict meat physico-chemical composition of guinea fowl (Numida meleagris) reared under different production systems. Food chemistry, 113(4): 1290-1296.

Wybenga, D. R., V. J. Pileggi, Ph H. Dirstine, and John Di Giorgio. 1970. Direct manual determination of serum total cholesterol with a single stable reagent. Clinical Chemistry 16(12): 980-984.

\section{How to cite this article:}

Nandini Devi, T., R. Ramani, R. Narendra Babu, V. Appa Rao, J. Ramesh and Robinson J.J. Abraham. 2017. Effect of Cooking on Cholesterol and Proximate Composition on Breast and Thigh Muscles of Chicken and Quail Meat. Int.J.Curr.Microbiol.App.Sci. 6(10): 3700-4703. doi: https://doi.org/10.20546/ijcmas.2017.610.434 